\title{
Molecular Approaches to Agri-Food Traceability and Authentication: An Updated Review
}

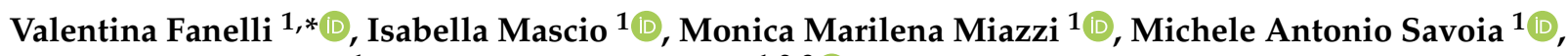 \\ Claudio De Giovanni ${ }^{1}$ and Cinzia Montemurro ${ }^{1,2,3}$ (D) \\ 1 Department of Soil, Plant and Food Sciences, University of Bari Aldo Moro, Via Amendola 165/A, \\ 70126 Bari, Italy; mascioisa@gmail.com (I.M.); monicamarilena.miazzi@uniba.it (M.M.M.); \\ michele.savoia@uniba.it (M.A.S.); claudio.degiovanni@uniba.it (C.D.G.); cinzia.montemurro@uniba.it (C.M.) \\ 2 Spin off Sinagri s.r.l., University of Bari Aldo Moro, Via Amendola 165/A, 70126 Bari, Italy \\ 3 Institute for Sustainable Plant Protection-Support Unit Bari, National Research Council of Italy (CNR), \\ Via Amendola 122/D, 70126 Bari, Italy \\ * Correspondence: valentina.fanelli@uniba.it
}

check for updates

Citation: Fanelli, V.; Mascio, I.; Miazzi, M.M.; Savoia, M.A.; De Giovanni, C.; Montemurro, C. Molecular Approaches to Agri-Food Traceability and Authentication: An Updated Review. Foods 2021, 10, 1644. https://doi.org/10.3390/ foods10071644

Academic Editor:

Raúl González-Domínguez

Received: 17 June 2021

Accepted: 15 July 2021

Published: 16 July 2021

Publisher's Note: MDPI stays neutral with regard to jurisdictional claims in published maps and institutional affiliations.

Copyright: (c) 2021 by the authors. Licensee MDPI, Basel, Switzerland This article is an open access article distributed under the terms and conditions of the Creative Commons Attribution (CC BY) license (https:// creativecommons.org/licenses/by/ $4.0 /$ )

\begin{abstract}
In the last decades, the demand for molecular tools for authenticating and tracing agri-food products has significantly increased. Food safety and quality have gained an increased interest for consumers, producers, and retailers, therefore, the availability of analytical methods for the determination of food authenticity and the detection of major adulterations takes on a fundamental role. Among the different molecular approaches, some techniques such as the molecular markers-based methods are well established, while some innovative approaches such as isothermal amplificationbased methods and DNA metabarcoding have only recently found application in the agri-food sector. In this review, we provide an overview of the most widely used molecular techniques for fresh and processed agri-food authentication and traceability, showing their recent advances and applications and discussing their main advantages and limitations. The application of these techniques to agrifood traceability and authentication can contribute a great deal to the reassurance of consumers in terms of transparency and food safety and may allow producers and retailers to adequately promote their products.
\end{abstract}

Keywords: molecular traceability; authentication; agri-food; molecular markers; DNA barcoding; isothermal amplification; sequencing

\section{Introduction}

The major worries of consumers concern the origin and the safety of the food they buy. The increased awareness of the value of food quality induces the consumer to ask for transparency from food companies. At the same time, companies must be able to certify the content and origin of their products with the aim of protecting the consumer against fraud and adulterations. In this scenario, traceability and authentication are fundamental tools for reassuring consumers in terms of transparency and food safety and allowing producers to gain awareness of the value of their products. Traceability lets the tracking of the source of a food at any point in the production chain enabling the quality-control processes and cutting down the production of unsafe or poor-quality foods [1]. Food authentication is the process through which a food is tested to verify if it complies with the description contained in its label [2].

Traceability and authentication are integral components of the food safety and defense system and represent fundamental components of the food supply chain. A reliable authentication and traceability system can constitute an essential instrument for the protection of consumers, reducing the chance of people consuming adulterated or contaminated foods, and increasing supplier control and process safety. Consumers showed limited knowledge about the importance of authentication and traceability of food products $[3,4]$, making 
essential the dissemination of the potential and reliability of tracing methods with the purpose to increase people's awareness of the role of food surveillance in health protection and the truthfulness of traceability information.

A wide variety of analytical methods for food traceability and authentication have been developed and tested [5]. Each method allows obtaining specific information on food composition and characteristics such as geographical origin, presence of adulterants, and species or varieties used in the production process. Among these analytical methods, the molecular approaches show some important advantages such as accuracy, sensitivity, and high reproducibility. Moreover, these methods are not affected by environmental changes, harvesting period, storage condition, and manufacturing process [6].

In the last decades, the demand for molecular tools for food authentication and traceability has significantly increased. This is mainly due to increasingly stringent legislation in the food sector and the market strategies aiming to assess a uniform and reliable control of the whole food chain from the field to the market and to ensure that consumer choices correspond to their expectations [7]. In this context, the European Union established two levels of recognition of food products: Protected Designation of Origin (PDO) and Protected Geographical Indication (PGI) with the purpose to protect the typical and local products and help consumers in choosing authentic food products and avoiding food frauds [8]. The DOP mark recognizes foods whose main characteristics depend on the territory of origin and the adherence to strict production rules. The IGP mark is attributed to a food that has a specific quality dependent on the specific geographical area of production. The availability of molecular analytical approaches is fundamental in the assessment of the conformity of PDO/PGI labels and the detection of not declared components.

Among the molecular analytical methods, some techniques such as the molecular markers-based approaches are well established, while some innovative approaches such as isothermal amplification-based methods and DNA metabarcoding have only recently found application in the surveillance of agri-products. Different authors have reviewed the most commonly used molecular methods for agri-food authentication [5,6,9-11], however, none of them have described the most recent and advanced techniques in detail and the potential of these methods in traceability and authentication processes.

In this review, an overview on the principal analytical methods for agri-food authentication and traceability was provided, focusing in particular on the molecular approaches. We describe some of the proven and widely tested molecular approaches such as molecular markers-based methods, showing their latest applications in agri-food surveillance. Moreover, we explore the most recent technologies describing their potential and prospects in food authentication and traceability. Finally, the advantages and limits of each approach are described and discussed.

\section{Analytical Methods for the Traceability and Authentication of Food Deriving from Plant Species}

In the last twenty years, an exponential growth of studies on methods for the traceability of animal- and plant-based food has been observed [12,13]. For animal-based food, the main frauds concern the substitution of an ingredient and the animal's geographical origin. In these cases, the analytical approaches are mainly based on vibrational spectroscopic techniques for the identification of the geographical origin and DNA typing of animal species [12]. For plant-based food, the fraudulent practices are highly disparate. The mismatch between product origin and geographical origin declared on the food label, the adulteration and contamination of product, the use of different species or different varieties compared with those declared on the label and the level of an additive higher than that permitted in a specific food are the most common frauds. Traceability approaches used for agri-foods are varied. Table 1 shows a list of the principal physico-chemical approaches used for plant-based food product traceability and authentication and the most recent reviews published for each method. 
Table 1. Summary of the most recent reviews about the principal methods based on physico-chemical analysis for agri-food traceability and authentication and the food matrices on which they are commonly used.

\begin{tabular}{|c|c|c|}
\hline Analytical Method & Food Products & References \\
\hline Vibrational spectroscopic techniques & Different agri-food products & Lohumi et al. [14] \\
\hline Mass spectrometry techniques & Different agri-food products & Castro-Puyana and Herrero [15] \\
\hline Stable isotope analysis & Cereals, wine, and vegetable oils & Zhao et al. [16] \\
\hline $\begin{array}{c}\text { Gas chromatography coupled with mass } \\
\text { spectrometry }\end{array}$ & $\begin{array}{c}\text { Wine, hazelnuts, barley, terebinth, olive oil, coffee, } \\
\text { vegetables, and fruits }\end{array}$ & Dymerski [17] \\
\hline HPLC & Olive oil, coffee, tea, wine, juice, fruit, nuts & Esteki et al. [18] \\
\hline Gas chromatography & Wine, chocolate, coffee, saffron, vegetable oil, fruit & Nolvachai et al. [19] \\
\hline Spectroscopic and spectrometric techniques & $\begin{array}{c}\text { Wine, vegetable oils, coffee, wheat, nuts, rice, } \\
\text { vegetables and fruits }\end{array}$ & Medina et al. [20] \\
\hline ELISA & Different agri-food products & Wu et al. [21] \\
\hline Fluorescence spectroscopy & Vegetable oils, cereals, vegetables and fruits & Ahmad et al. [22] \\
\hline Spectroscopic techniques & Vegetable oils, coffee, wine, fruit juice & Esteki et al. [23] \\
\hline Raman spectroscopy & Olive oil, coffee, wine, rice & Xu et al. [24] \\
\hline NMR & Balsamic vinegar, saffron, coffee, tomato & Consonni and Cagliani [25] \\
\hline Mass spectrometry techniques & Wine, fruit juice, olive oil, beer, coffee & Rubert et al. [26] \\
\hline Spectroscopic and spectrometric techniques & Different agri-food products & Wadood et al. [13] \\
\hline
\end{tabular}

Chromatography allows for the separation and quantification of macro- and microcomponents in food products. The most widely used chromatographic techniques are high-performance liquid chromatography (HPLC) and gas chromatography. Both methods have been successfully used for the identification of the geographical origin of sweet cherry cultivars [27]. For agri-products, HPLC is an effective method to detect the presence of adulterants, quantify the level of additives, and identify the geographical origin of the product. The HPLC technique has been efficiently used for the authentication of extra virgin olive oil, the detection of adulteration in fruit juice, and the identification of the geographic origin of coffee, tea, and wine [18]. Gas chromatography is mostly applied in volatile substances analysis and detection of contaminants like pesticides. Gas chromatography analysis was performed to identify the geographical origin of different kinds of plant-based food products [13,19].

Immunoassays are analytical tools based on the use of antibodies or enzymes as recognition elements to detect the presence of specific antigens. Enzyme-linked immunosorbent assay (ELISA) is the most used immunological method for food traceability. This technique is mostly used for the detection of pesticide residues in food-borne matrices [28,29].

Spectroscopic techniques are fast and inexpensive methods based on the use of radiated energy to analyze the properties of a specific element. They have been widely used for different purposes including agri-food traceability. Fluorescence spectroscopy is a non-invasive and relatively inexpensive technique. However, it is less used compared to other spectroscopic methods due to its low detection limit. Despite this, fluorescence spectroscopy has been successfully used to detect adulteration in edible vegetable oils [30]. Vibrational spectroscopy is a widely used spectroscopic technique in the food sector. A wide array of vibrational spectroscopic methods including near-infrared (NIR), Fourier transform infrared (FTIR), and Raman spectroscopy have been used for the detection of adulteration and determining the authenticity of food products [14].

Nuclear magnetic resonance (NMR) allows for the identification of the composition of complex matrices of foodstuffs. The amount of any component in a mixture can be assessed with high precision. In the last years, NMR has been widely used for geographical traceability of agri-food products. This technique has been efficiently applied to the traceability of balsamic vinegar, saffron, coffee, and tomato [25], and recently to discriminate the origins of different species including rice, lentil, and citrus [31-33].

Among the most efficient methods for food authentication are the mass spectrometry (MS) techniques. A wide array of MS applications is available for food traceability and safety purposes such as the detection of contaminants, the composition, and the origin of a product [15]. Two MS techniques, isotope ratio mass spectrometry (IRMS), multi collector-inductively coupled plasma-mass spectrometry (MC-ICP-MS), are commonly used for the analysis of isotopic ratios in food matrices. The isotopic ratios are widely used 
in food authentication and traceability because they change with the area of origin of the product, climatic conditions, characteristics of soil, and agricultural practices. The most commonly used isotope ratios of elements for traceability of agri-products are ${ }^{13} \mathrm{C} /{ }^{12} \mathrm{C}$ and ${ }^{15} \mathrm{~N} /{ }^{14} \mathrm{~N}$, influenced by climate condition and agricultural practices; ${ }^{2} \mathrm{H} /{ }^{1} \mathrm{H}$ and ${ }^{18} \mathrm{O} /{ }^{16} \mathrm{O}$, affected by the area of origin; and ${ }^{34} \mathrm{~S} /{ }^{32} \mathrm{~S}$, influenced by geology [34]. Several studies have applied the analysis of isotopic ratios to identify the origin of agri-products [16].

Usually, the food traceability and authentication methods based on physico-chemical analysis are used in combination with each other in order to reach maximum sensitivity and reliability. The combined use of gas chromatography with mass spectrometry allows for accurate qualitative and quantitative analyses of complex mixtures providing noteworthy results in the surveillance of agri-products [17]. A recent study showed that the combined analysis of stable isotopes, elemental composition, and chemical markers was demonstrated to be highly effective in the determination of the geographical origin of a product [35].

Although over the years these analytical methods have been proven to be highly efficient and reliable in the identification of the geographical origin and potential adulterants fraudulently added to a product, they show remarkable limitations in the detection of contaminant species and in unmasking the use of varieties not declared in the product label. Additionally, physico-chemical approaches have been shown to be highly reliable with fresh products while they tend to lose effectiveness in the analysis of processed foods. These limitations are overcome by the use of molecular methods to food traceability.

\section{Molecular Approaches to Agri-Food Analysis}

DNA is a stable molecule present in all living organisms and each organism's DNA sequence is unique, enabling the distinguishing of the species and varieties used to produce a specific food. Moreover, DNA can also be recovered in enough quality and quantity in heavily processed food matrices. Thanks to the recent advancements in molecular biology and genetics, molecular approaches have become powerful and widely used methods for the authentication of agri-food products and for tracking the raw materials across the whole industry process. Along with the most widespread and experienced molecular marker-based methods, the more recent isothermal amplification-based methods, digital PCR techniques, and NGS-based approaches appear to be very promising in the traceability of a wide range of fresh and processed agri-foods. Table 2 shows a list of the most recent studies on agri-food authentication and traceability using DNA-based approaches.

Table 2. List of the most recent studies on DNA-based methods applied in the traceability and authentication of agri-foods.

\begin{tabular}{|c|c|c|c|}
\hline Technique & Agri-Food Product & Detected Species & References \\
\hline SSR/capillary electrophoresis & Grapes, must, and wine & Grapevine (Vitis vinifera L.) & [36] \\
\hline SSR/HRM and SNP/HRM & Olive oil & Olive (Olea europea L.) & [37] \\
\hline SSR/HRM & Olive oil & Olive (Olea europea L.) & [38] \\
\hline $\begin{array}{l}\text { SSR/capillary electrophoresis and } \\
\text { SSR/HRM }\end{array}$ & Must and wine & Grapevine (Vitis vinifera L.) & [39] \\
\hline SNP/PCR-RFLP & Olive oil & Olive (Olea europea L.) & [40] \\
\hline $\begin{array}{l}\text { SSR/capillary electrophoresis and } \\
\text { SNP/Sanger sequencing }\end{array}$ & Extra virgin olive oil & Olive (Olea europea L.) & {$[41]$} \\
\hline SNP/HRM & Must and wine & Grapevine (Vitis vinifera L.) & [42] \\
\hline TaqMan SNP Genotyping Assay & Must and wine & Grapevine (Vitis vinifera L.) & [43] \\
\hline $\mathrm{SNP} /$ biosensor & Must and wine & Grapevine (Vitis vinifera L.) & [44] \\
\hline $\mathrm{SNP} /$ nanofluidic array & Coffee beans & $\begin{array}{c}\text { Coffee (Coffea arabica L. and Coffea canephora } \\
\text { Pierre ex. A. Froehner). }\end{array}$ & [45] \\
\hline $\begin{array}{l}\text { Species-specific primer } \\
\mathrm{PCR} / \text { sequencing }\end{array}$ & Flour, pasta, bread, and cookies & Common wheat (Triticum aestivum L.) & [46] \\
\hline $\begin{array}{l}\text { Species-specific primer } \\
\text { /digital PCR }\end{array}$ & Flour and pasta & Common wheat (Triticum aestivum L.) & [47] \\
\hline
\end{tabular}


Table 2. Cont.

\begin{tabular}{|c|c|c|c|}
\hline Technique & Agri-Food Product & Detected Species & References \\
\hline $\begin{array}{l}\text { Species-specific primer } \\
\text { /digital PCR }\end{array}$ & Lotus seed paste & White kidney bean (Phaseolus vulgaris L.). & {$[48]$} \\
\hline DNA barcoding/sequencing & Nutmeg mace & Nutmeg tree (Myristica fragrans Houtt) & {$[49]$} \\
\hline $\begin{array}{l}\text { DNA barcoding/capillary } \\
\text { electrophoresis }\end{array}$ & Almond oil and almond kernels & Almond (Prunus dulcis Mill.) & {$[50]$} \\
\hline Bar-HRM & Tea products & Tea (Camellia sinensis L.) & [51] \\
\hline Bar-HRM & Nut species and walnut milk beverage & $\begin{array}{l}\text { Walnut (Juglans regia L.), pecan (Carya } \\
\text { illinoensis K. Koch), hickory (Carya cathayensis } \\
\text { Sarg.), and peanut (Arachis hypogaea L.) }\end{array}$ & [52] \\
\hline Bar-HRM & Raw seeds and ground coffee & $\begin{array}{c}\text { Coffee (Coffea arabica L. and Coffea canephora } \\
\text { Pierre ex. A. Froehner). }\end{array}$ & [53] \\
\hline $\begin{array}{l}\text { DNA barcoding/ } \\
\text { NanoTracer strategy }\end{array}$ & Saffron powder & Saffron (Crocus sativus L.) & [54] \\
\hline $\begin{array}{l}\text { DNA barcoding/ } \\
\text { sequencing }\end{array}$ & Berry fruit and fruit juice & Different taxa & [55] \\
\hline RPA-LFD & Saffron powder & Saffron (Crocus sativus L.) & [56] \\
\hline DNA barcoding/LAMP & Saffron powder & Saffron (Crocus sativus L.) & [57] \\
\hline LAMP & Durum wheat products & $\begin{array}{c}\text { Durum wheat variety Aureo (Triticum } \\
\text { turgidum var. durum L.) }\end{array}$ & {$[58]$} \\
\hline DNA barcoding/LAMP & Fruit juice & $\begin{array}{c}\text { Pomegranate (Punica granatum L.), Apple } \\
\text { (Malus domestica (Suckow) Borkh.), and grape } \\
\text { (Vitis vinifera L.) }\end{array}$ & [59] \\
\hline Whole metagenome sequencing & Different herbal products & Different taxa & {$[60]$} \\
\hline Whole metagenome sequencing & Lupin seed, flour, and cookies & Lupin (Lupinus spp.) & [61] \\
\hline $\begin{array}{l}\text { Whole chloroplast } \\
\text { genome sequencing }\end{array}$ & Dried fruit & $\begin{array}{l}\text { Different species of aromatic trees } \\
\text { (Zanthoxylum spp.) }\end{array}$ & [62] \\
\hline $\begin{array}{l}\text { Whole chloroplast } \\
\text { genome sequencing }\end{array}$ & Berry fruit & Different berry species (Vaccinium spp.) & [63] \\
\hline DNA metabarcoding & Honey & Different taxa & [64] \\
\hline DNA metabarcoding & Honey & Different taxa & [65] \\
\hline
\end{tabular}

\subsection{Molecular Marker-Based Methods}

Molecular marker-based methods are the most widely used techniques for food traceability. The main reasons are the reduced amount of template DNA required for marker detection, the chance to analyze simultaneously multiple target regions, and the possibility of obtaining both qualitative and quantitative information. In most cases, PCR-based methods are used to detect molecular marker variations [9]. PCR is diffusely employed in all molecular biology laboratories and does not require highly qualified personnel. Moreover, the low cost of the equipment and reagents makes PCR-based detection the easiest and most inexpensive method for molecular authentication and traceability of agri-products. The types of molecular markers most used for traceability purposes are microsatellite or Simple Sequence Repeat (SSR) and Single Nucleotide Polymorphism (SNP). They are highly informative due to their large number and even distribution throughout the genome and can highlight both inter and intra-species diversity [10].

\subsubsection{Simple Sequence Repeats (SSR)}

Over the last ten years, the number of works based on the use of SSR for agri-food traceability and authentication has progressively reduced, together with an increase in papers employing the more abundant and stable SNP markers (Figure 1), nevertheless, SSR remains the most widely used marker for molecular traceability. Simple sequence repeats are tandem repeated motifs of 2-6 bp flanked by highly conserved sequences. The polymorphism is due to the different number of repeats in the microsatellite region, and can be easily detected by PCR. Their high reproducibility and polymorphism degree make them a marker of choice for many applications including varietal identification and adulteration detection [66]. 


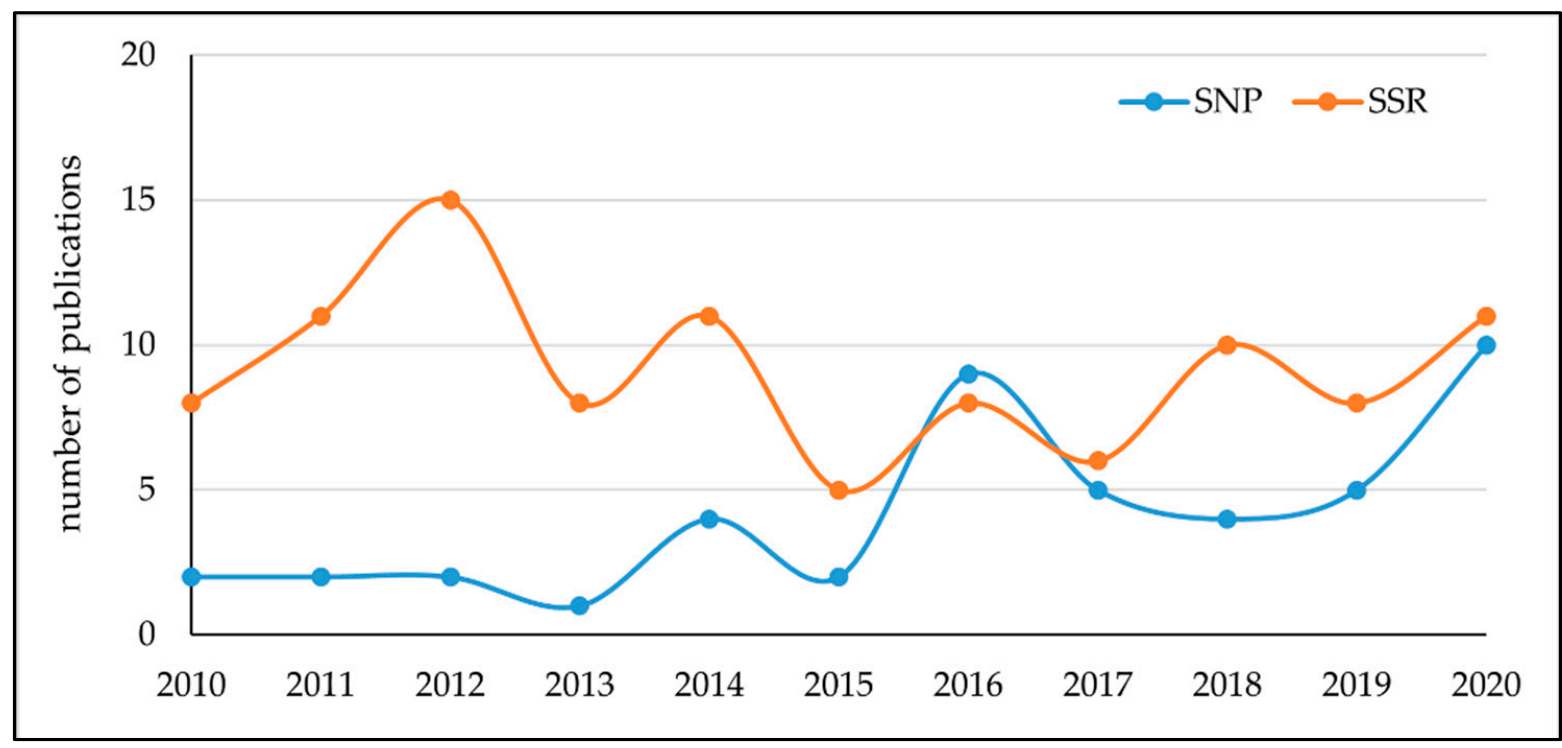

Figure 1. Number of publications per year in traceability and authentication of agri-foods through SSR and SNP markers. Data were obtained by searching the Scopus document archive (https: / / www.scopus.com; accessed on 8 June 2021) for English language articles for years between 2010 and 2020 using the following search terms: (SSR) AND (authentic*), (SSR) AND (traceability), (SNP) AND (authentic*) and (SNP) AND (traceability) and selecting only publications related to the agri-food sector and relevant to authentication and traceability processes.

Recently, SSRs have been efficiently used for the traceability of cocoa in beans and liquor [67], evaluations on trueness-to-type of raspberry [68] and olive [69] varieties, and to trace monovarietal and polyvarietal wines along the entire production chain [36]. Microsatellite markers have also been shown to be effective in tracing species characterized by a reduced diversity such as zucchini [70]. The most common approach involves the amplification of the regions of interest followed by fragment size evaluation through capillary electrophoresis. Nevertheless, the analysis of amplicons by the high resolution melting (HRM) assay was revealed to be highly effective in the authentication of PDO sweet cherry products [71] and the detection of adulteration in lentil [72]. Besides, the SSR-HRM technique allows for the authentication and traceability of processed food such as olive oil and wine. In particular, the combined use of SSR markers and HRM allows for distinguishing the varietal composition of olive oil and wine blends determining a limit of detection for adulteration included between $1 \%$ and 2.5\% [37-39,73]. Moreover, microsatellite detection through real-time PCR enables the quantification of a specific contaminant. Pasqualone et al. [74] identified the common wheat contamination in durum wheat semolina and bread through the detection of genome D-specific SSR. The authors observed a detection limit of 3\% and 5\% for semolina and bread, respectively, by qualitative PCR lowered to $2.5 \%$ by real-time PCR.

\subsubsection{Single Nucleotide Polymorphism (SNP)}

Single nucleotide polymorphisms (SNPs) are variations in the DNA sequence involving a single base. They are the most abundant and ubiquitous markers in any living organism and their diallelic nature offers a lower error rate in allele calling compared with other molecular markers. Moreover, SNPs identification does not require DNA separation by size, and it is suitable for automation, making the analysis quick and reproducible.

SNPs are widely used in the traceability of animal-based foods, especially in the genetic authentication of meat [75], while only a few works are available in the agrifood sector, however, their use in this field has increased significantly in the last years and it is expected to keep growing in the future (Figure 1). The development of SNPbased approaches to agri-food traceability is encouraged by the increasing number of SNP 
catalogs mostly derived by GBS analysis. These panels are available in different species of agri-food interest such as grapevine, olive, pulses, cacao, and coffee [76-80]. Most of the works using a SNP-based traceability approach have focused on olive oil analysis [40,41], however, SNPs have been efficiently employed in differentiating Arabica and Robusta coffee varieties [81], in the authentication of Portuguese wine [42], and in the identification of Nebbiolo variety in musts and wines [43].

SNP identification is suitable for different detection methods such as single-base primer extension, cleaved amplified polymorphic sequences assays (CAPS), HRM, and sequencing techniques. Recently, an innovative system for wine authenticity based on the use of a biosensor as the system of SNP detection was developed by Barrias et al. [44]. DNA-based biosensors use DNA strands as probes for sensing DNA targets, distinguishing among samples differing for a single nucleotide in their sequence. The authors demonstrated the ability of the system to discriminate the varieties present in leaf, must, and wine samples, showing the promising application of this technique in SNP-based agri-food authenticity. Additionally noteworthy is the SNP genotyping system based on the use of a nanofluidic array. This system consists of the use of integrated fluidic circuits for high-throughput real-time PCR, allowing for the reliable analysis of multiple samples in a short time using small quantities of DNA. The nanofluidic SNP protocol has been successfully applied for cultivar authentication and identification of the adulterant varieties in cacao beans [82], discrimination of 40 tea varieties [83], and cultivar differentiation of coffee beans [45].

The rapid advances of next generation sequencing technologies have allowed for the automation of SNP detection, making the analysis based on this marker more rapid and reliable [84]. The employment of innovative sequencing approaches will allow the further spread of SNP-based approaches in the safeguarding of agri-food safety and quality.

\subsection{Single Region Approaches}

For some applications, the investigation focuses on a specific and well-known target DNA region. The analysis can be performed with the purpose to amplify a DNA sequence of a specific species or variety, taking advantage of peculiar differences in that region (e.g., indels). Conversely, PCR primers can be designed in a specific conserved region to amplify a sequence characterized by a certain polymorphism among species. This is the case of the DNA barcoding approach, representing an important tool for food traceability and authentication [85]. Isothermal amplification-based methods seem to be very promising and represent a novel group of nucleic acid amplification technologies that are simple and highly specific. Recently, these strategies have been successfully applied in the agri-food authentication sector.

\subsubsection{Species-Specific Primer PCR}

The presence of differences in nucleotide sequence or indels allows for the design of primers specific for a species or a variety. The detection of an amplification product makes possible the identification of adulterant species or variety in a particular food-borne sample. This approach has been widely used for the detection of common wheat in durum wheatbased products such as pasta or durum wheat bread. The identification of the presence of common wheat can be addressed by the detection of a sequence-specific of the D-genome, which is present in hexaploidy wheat but absent in durum wheat. Sonnante et al. [86] focused on the microsatellite region GDM111 to develop a quantitative method to detect the common wheat contamination in semolina, bread, and pasta products. The method was revealed to be effective up to a limit of $1 \%$ common wheat contamination. Matsuoka et al. [87] employed the Starch Synthase II (SS II) gene, coded on wheat A, B, and D genomes. The authors took advantage of some differences in the SS II-D gene to set up a qualiquantitative method for the detection of common wheat in blended flour. Silletti et al. [46] used a tubulin-based polymorphism to develop an assay specific for the detection of common wheat adulteration in pasta and flour. Through a DNA-based multiplex detection 
tool, Voorhuijzen et al. [88] were able to simultaneously test 15 different grain ingredients within one food with high accuracy.

In recent years, the development of techniques based on digital PCR (APCR) has made the detection of a contaminant in food much faster and easier [89]. Digital polymerase chain reaction enables absolute quantification of a target nucleic acid in a sample even when the target is present at a very low number of copies. dPCR works by partitioning DNA fragments into thousands of independent droplets or chips, making it possible to directly count the number of target molecules through Poisson statistics [90]. dPCR has been widely used in the field of genetically modified organism (GMO) monitoring [91] and for pathogen diagnostics [92]. Moreover, this technique was also revealed to be very reliable and accurate in food safety and adulteration control. Pierboni et al. [93] efficiently applied droplet digital PCR to detect the presence of peanut and soybean allergens in mill and bakery products and demonstrated the usefulness of this technique for the food safety of allergic populations. More recently, Morcia et al. [47] developed a duplex chip digital PCR assay able to identify and quantify common wheat presence along the whole pasta production chain. The authors found that the limit of detection of the proposed method was $0.3 \%$ common wheat contamination, whereas the limit of quantification was found at the $1.5 \%$ level. Duplex droplet digital PCR and chip digital PCR were also revealed to be effective in the quantitative detection of kidney beans in lotus seed paste [48]. Generally, lotus seed paste is adulterated with cheaper ingredients such as common beans, making the detection method based on digital PCR extremely useful in revealing fraudulent substitutions or adventitious contaminations.

\subsubsection{DNA Barcoding}

DNA barcoding was developed by Hebert et al. [94] and is based on the analysis of variability within a specific genomic region called the "DNA barcode". This method represents an effective approach to food traceability and authenticity since it does not require extensive knowledge of the genome sequence of each organism and allows for the identification of more than one species at the same time. In animal-based food traceability, the barcoding is frequently based on the amplification of the cytochrome oxidase gene. In terrestrial plants, plastidial genes $r b c L$ and $m a t K$, the trnH-psbA intergenic spacer and nuclear ITS2 sequence are mostly used as barcode regions [85]. DNA barcoding efficiency has been widely demonstrated in discriminating spices species such as nutmeg [49]. Recently, the analysis of trnH-psbA spacer and ITS2 sequence revealed them to be effective in the authentication of ginseng products [95] and the identification of adulterants in coffee and almond [50,96].

Frequently, DNA barcoding is employed coupled with high resolution melting (HRM) analysis (Bar-HRM). It consists in the amplification of a short DNA barcoding sequence and target region detection through HRM based on the distinctive melting behavior due to differences in DNA sequence. In the last years, the Bar-HRM strategy has found a large spread in agri-food surveillance. Bosmali et al. [97] set up a fast and cost-effective Bar-HRM method for PDO saffron authentication. The proposed approach was revealed to be highly effective in terms of specificity and sensitivity compared to other methods. A similar approach was used for the authentication of commercial sea buckthorn products [98]. More recently, Bar-HRM was employed for the authentication of several commercial tea products and detection of the presence of cashew DNA in the tea products [51], identification of common nut adulterants in walnut milk beverage [52], and the quantitative detection of Robusta traces in Arabica coffee products [53]. The great potential of the Bar-HRM technique has been widely demonstrated by Ballin et al. [99]. In this study, a DNA profiling platform for species authentication throughout the plant kingdom was developed through a multiplexed Bar-HRM approach. Distinct melting profiles were obtained for species originating from 29 different families spanning the angiosperms, gymnosperm, mosses, and liverwort, demonstrating the ability of the proposed approach in discriminating a large number of species without a priori knowledge of the species' DNA sequence. 
DNA barcoding-based approaches in agri-food authentication and traceability are promising thanks to the great advances made in molecular biology techniques that allow us to combine the detection of a specific barcode sequence with modern technologies such as nanotechnologies. Based on this principle, Valentini et al. [54] developed an easy and inexpensive approach called "Nanotracer", which is able to detect the presence of a specific species-DNA in a food sample through a colorimetric response. The proposed approach is based on an asymmetric PCR amplification of a short barcode region, yielding a singlestrand amplicon that is readily hybridizable to induce a color change due to the presence of DNA-functionalized gold nanoparticles. This method offers a rapid and naked-eye authentication test, and its implementation in the agri-food sector will provide an efficient system for food surveillance in the future.

The potential of the DNA barcoding strategy can be exploited through the sequencing of amplicons. The obtained sequence can be used to differentiate and univocally identify the species present in a food sample through a comparison with specific molecular databases. Recently, Sanger sequencing of specific DNA barcode regions was efficiently used for authentication of small berries in fruit products [55] and the construction of a DNA barcode library for the traceability of Chinese herbs [100]. However, the high costs and the limited number of samples that could be analyzed at the same time, along with the necessity of high-quality DNA, led Sanger sequencing to be supplanted by the next generation sequencing (NGS) technologies, which offer a much higher throughput through a less expensive and less time-consuming procedure.

The adoption of a universal barcode shows evident limits at the cultivar level, where genetic variability is limited. To overcome these limits, the ultra-barcoding methodology was proposed [101] to obtain a varietal identification. This strategy is based on the sequencing of the whole plastidial genome and a portion of the nuclear genome through NGS technologies. Ultra-barcoding has been shown to be a highly reliable strategy in cacao authentication [102].

The use of the DNA barcoding method in the agri-food sector is supported by the availability of the Barcode of Life Database (BOLD) coordinated by the International Barcode of Life Project [103]. This database contains a reference library for all living species, allowing the identification of more than 300,000 species on the base of the barcode sequence. Moreover, it includes a comprehensive registry of primers useful in the generation of barcode sequences. BOLD is a reliable resource for the exploitation of the potentiality of the DNA barcoding approach in food authenticity and safety.

\subsubsection{Isothermal Amplification-Based Methods}

Isothermal amplification-based techniques represent a promising alternative to classical PCR since they achieve rapid and efficient detection of a nucleic acid target without requiring the use of a thermocycler. These methods allow the amplification of a specific region in an exponential manner at a constant temperature. Over the last decade, various techniques based on isothermal amplification have been developed; although their features can vary among the different methods, they share some characteristics such as the use of a polymerase with strand-displacement activity. Some of the isothermal amplification techniques mostly used in agri-food surveillance are rolling circle amplification (RCA), multiple displacement amplification (MDA), recombinase polymerase amplification (RPA), and loop-mediated isothermal amplification (LAMP). These methods are mostly used in the detection of various micro-organisms, representing an important instrument to control food-borne diseases and safeguard food safety and quality [104]. Furthermore, they were also revealed to be highly sensitive and efficient in agri-food authentication and traceability. RPA in combination with ELISA has been shown to be highly effective in the detection of allergens such as hazelnut, peanut, and soybean as well as undeclared food ingredients [105]. Recently, Zhao et al. [56] proposed a novel analysis based on the combined use of RPA and lateral flow device (RPA-LFD) for saffron authentication. This rapid assay was revealed to be highly sensitive and specific, with no cross-reaction with common saffron adulterants. 
Among the isothermal amplification-based methods, LAMP is the most widely used. This technique employs four to six different primers able to recognize six to eight different sequences of a target region, allowing the synthesis of large amounts of DNA in a short time. The amplification products are stem-loop DNAs with different inverted target repeats; these products can be detected with different methods including real-time assay and naked-eye detection through DNA-binding dyes or colorimetric indicators [106]. The high specificity, efficiency, and simplicity of the LAMP method has led to its application in the identification of different micro-organisms including food-related pathogens [107]. This approach is also suitable for the detection of GMOs through the employment of commonly used promoters or marker genes as LAMP targets [108]. Recently, LAMP has also assumed a relevant role in agri-food surveillance for the identification of specific species or even a variety in a specific food product. This approach has been used to authenticate saffron and discover its adulterants such as safflower and turmeric [57]. Cibecchini et al. [58] set up a portable colorimetric LAMP-based method to detect the presence of a specific wheat variety (Aureo) in grains and flours. Hu and $\mathrm{Lu}$ [59] developed a device for the specific detection of pomegranate, apple, and grape DNA present in fresh fruit juice. The authors combined DNA extraction and LAMP reaction in a hybrid paper/polymer-based lab-on-a-chip platform, allowing for the quick detection of a specific species in a juice sample through the use of a fluorescent dye. In the future, this method is expected to play an important role in the field of agri-food authentication and traceability.

\subsection{Next Generation Sequencing-Based Methods}

DNA sequencing represents the easiest way to detect multiple species and varieties present in a specific food-borne sample. Traditional Sanger sequencing allows for the detection of a specific DNA region at a time. Although cloning may improve resolution, it requires numerous steps and is very time-consuming. Moreover, Sanger sequencing is a relatively slow method, producing reads with a length not exceeding $900 \mathrm{bp}$ [109]. Next generation sequencing (NGS) is a high throughput technique enabling the generation of different quantities and lengths of DNA sequencing. The different approaches are commonly grouped based on the length of reads produced during the sequencing. Therefore, we distinguished between short-read and long-read sequencing methods defined as secondand third-generation technologies, respectively.

The short-read sequencing approaches such as sequencing by synthesis and ion semiconductor sequencing were the first NGS techniques to be developed. Illumina is the current leader for the short-read sequencing approach. This technique is based on the peculiar bridge amplification method and the sequencing by synthesis strategy, which generates long-reads up to $300 \mathrm{bp}$ [110]. Another popular short-read strategy is the ion semiconductor sequencer Ion Torrent based on the use of a dedicated sensor that acts as a highly sensitive $\mathrm{pH}$ meter, which detects the hydrogen ion release associated with nucleotide incorporation into the growing strand. For authentication of processed foods, the short-read-based sequencing strategies are preferable since DNA recovered from these matrices is usually highly degraded.

Third-generation strategies are quite recent techniques that enable overcoming many of the limitations of short-read sequencing through the sequencing of a single DNA/RNA molecule and generating reads with a length between $1 \mathrm{~kb}$ and $2 \mathrm{Mb}$ [110]. The main longread approaches are the single-molecule real-time sequencing (SMRT) and the nanopore sequencing. Despite the great potential of these techniques, their use is extremely limited in the food traceability sector. 
Although the use of NGS technologies has spread in several diagnostics and research sectors, their use in the field of agri-food molecular traceability remains limited. A possible explanation is that NGS technologies present high costs and require extensive computational power. In addition, these strategies require high-quality DNA, which is not always possible to recover from highly processed foods. Nevertheless, a certain number of studies on agri-food traceability and authentication through NGS-based approaches have been published. There are basically two adopted strategies: whole metagenome sequencing and DNA metabarcoding.

\subsubsection{Whole Metagenome Sequencing}

Whole metagenome sequencing (WMS) allows scanning for several species simultaneously even when these are present in a small quantity in a food matrix [111]. This approach is widely used in the food security sector to identify and characterize complex microbial communities in food samples [112]. An important advantage of using WMS in food-borne hurtful microbial detection is the possibility of also detecting non-culturable pathogens; moreover, the production of draft genome sequences of the bacteria responsible for food-borne alerts is also possible, allowing for the identification of contamination sources [113]. Likewise, WMS can be employed to trace specific species and even varieties with very high sensitivity and specificity. The analysis of whole genomes allows for the authentication and detection of non-approved species. Complex food matrices can be analyzed, and the detected reads assigned to corresponding organisms by comparison with "ad hoc" databases.

A software pipeline, called AFS (All-Food-Seq), was developed to quantitatively measure the species composition in food-borne samples. This pipeline takes advantage of the deep sequencing of total DNA, allowing for the identification of species components through the mapping of reads to publicly available reference genome sequences and the quantification of species proportions based on a sequence read counting approach. This method has been successfully applied for the traceability and authentication of different animal- and plant-based foods [111].

More recently, Haiminen et al. [114] set up a bioinformatic pipeline, FASER (Food Authentication from SEquencing Reads), to resolve the relative composition of mixtures of eukaryotic species using RNA or DNA sequencing. Moreover, they developed a comprehensive database including more than 6000 plants and animals that may be present in food. FASER was revealed to be a highly sensitive and accurate method to detect fraudulent substitutions or contaminations in the most disparate food matrices.

Whole metagenome sequencing has been proved to be very effective in the identification and authentication of herbal products [60] and the detection of contaminants in food processed samples [61]. In the latter work, the authors combined metagenomic sequencing and an alignment-free k-mer based approach for the identification of plant DNA in processed samples. In particular, they demonstrated that lupin DNA can be individuated in controlled mixtures of sequences from the target and closely related non-target species, showing that lupin-specific components are detectable in baked cookies containing a minimum of $0.05 \%$ of lupin flour in wheat flour.

The whole chloroplast genome can be sequenced as an alternative to nuclear DNA for food authentication purposes. This is particularly useful in highly processed agrifoods since organellar DNA is present in high copy numbers compared to nuclear DNA, preventing degradation occurring during the production process. The sequencing of chloroplast genome produces reads that can be compared to specific databases containing complete chloroplast genome sequences such as the GenomeTrakrCP, which is publicly available at the National Center for Biotechnology Information (https: / /www.ncbi.nlm. nih.gov / bioproject/PRJNA325670/; accessed on 24 May 2021) [115]. This approach has been demonstrated to be highly effective by several authors [62,63]. 


\subsubsection{DNA Metabarcoding}

The DNA metabarcoding approach combines the high throughput sequencing strategies with DNA barcoding, allowing the analysis of multiple amplicons corresponding to different barcode regions by sequencing them in parallel. The general strategy is based on extracting the whole DNA from certain foods, amplifying a specific barcode region whose dimensions can vary from 120 up to $600 \mathrm{bp}$, sequencing the corresponding amplicon, and analyzing the sequence using specific pipelines. This strategy is particularly suitable for highly processed foods since the DNA extracted from these matrices is usually degraded, making possible only the amplification of short regions [7]. Moreover, the DNA metabarcoding approach has also been demonstrated to be useful for quantitative analysis. In fact, differences in sequence reads abundance between species can be used to infer the corresponding differences in species abundance in a food sample [116].

The most commonly used plant barcode regions for DNA metabarcoding analysis are the nuclear ITS regions or the plastidial rbcL and psbA-trnH. In particular, the ITS1 and ITS2 regions have been used to identify plant components in herbal teas through their sequencing through two different platforms, Illumina and Ion Torrent, showing that both sequencing strategies are effective in qualitative and quantitative detection of different species [117]. Frigerio et al. [118] analyzed the sequence variability at DNA barcoding psbA-trnH and ITS and minibarcoding rbcL 1-B regions to trace medicinal and aromatic plants. Recently, a comprehensive ITS reference dataset called PLANiTS including all the ITS sequences of the Viridiplantae clade was developed [119]. The PLANiTS dataset represents a reliable first step toward an accurate standardization of plant DNA metabarcoding studies.

The effectiveness of DNA metabarcoding in the agri-food authentication and traceability sector has been widely demonstrated in the authentication of polyfloral and monofloral honey $[64,65,120]$. In these cases, the metabarcoding approach allowed not only for the identification of the botanical composition of honey, but also to investigate its geographical origin based on the genetic characterization of pollen content.

Recently, Gostel et al. [121] developed microfluidic enrichment barcoding (MEBarcoding) for high-throughput plant barcoding, a cost-effective method based on the combined use of the Fluidigm Access Array and Illumina MiSeq. This study enabled them to build a highly comprehensive barcode database and demonstrated that the proposed approach is efficient in discriminating a very large number of species present in a food-borne matrix at the same time.

\section{Advantages and Limits of Molecular Methods in Agri-Food Authentication and Traceability}

A wide variety of analytical techniques for authentication and traceability of agri-food products have been developed and tested. For a long time, chemical and biochemical approaches have been used for the detection of specific components in foodstuffs; nevertheless, in the last few decades, molecular techniques have taken the upper hand in the food surveillance sector. DNA-based methods are mostly used for the identification and quantification of species and varieties composed of fresh or processed food. Indeed, DNA is present in nearly all the cells of a given organism and its sequence remains unchanged during all production phases. Instead, proteins and secondary metabolites may be influenced by growing conditions, harvesting period, and storage environment [6]. Moreover, DNA is a much more resistant molecule to industrial transformation compared to other biological components. On the other hand, physical fragmentation and chemical treatment can affect the yield, integrity, and quality of DNA [11]. For this reason, several protocols for DNA extraction from processed agri-food matrices were developed with the aim to recover a sufficient amount of good-quality DNA for subsequent analysis (Table 3). These protocols were optimized to extract DNA from a specific food-borne product with the purpose of maximizing the yield while minimizing the coextraction of enzymatic reaction inhibitors. 
Table 3. List of the most recent protocols for DNA extraction from processed agri-foods and related references.

\begin{tabular}{ccc}
\hline Agri-Food Matrices & Method & Reference \\
\hline Must and wine & CTAB-based method/post-extraction purification & di Rienzo et al. [39] \\
Extra virgin olive oil & Hexane-based method & Piarulli et al. [41] \\
Nutmeg mace & SDS-based method & Hu and Lu [59] \\
Fruit juice & Filtration device & Xia et al. [122] \\
Soybean oil & CTAB-based method & Pereira et al. [123] \\
Wine & CTAB-based method & Bojang et al. [124] \\
Groundnut oil & DNA enrichment/CTAB-based method & Soares et al. [125] \\
Honey & CTAB-based method & López-Calleja et al. [126] \\
\hline
\end{tabular}

A valid alternative to nuclear DNA-based analysis is the use of approaches involving the chloroplast genome, which is present in high copy numbers in vegetal cells. Indeed, heavily industrial treatments can severely affect nuclear DNA quality and quantity, while this occurs to a lesser extent with chloroplast DNA due to its abundance [62,63].

Despite the significant advances that have been made in molecular techniques, innovative approaches are only partially used in agri-food authentication, while traditional molecular marker-based methods, whose effectiveness have been amply demonstrated, remain the approaches of choice. Regarding molecular marker-based methods, SNPs and SSRs are largely used nowadays because of their standardized and straightforward detection systems. These approaches are used mainly in the identification of plant varieties aiming to prevent fraudulent commercial activities. SNP and SSR application for food traceability and authentication offer several advantages: they have a high level of polymorphism, high reproducibility, and can be detected on a very small portion of DNA, which in the case of fragmented DNA may constitute an important advantage [127]. Moreover, recent technical advances in SNP detection have made this marker an election tool in food traceability. Indeed, modern sequencing technologies allow millions of SNPs to be processed, simultaneously making possible the analysis of several samples in extremely short times [128]. Nevertheless, being highly species-specific, the molecular marker-based methods require the knowledge of plant species putatively present in a food and access to the correct DNA sequence of interest. Therefore, their application is often limited to a single species [129].

Frequently, a food can contain several vegetal species and the availability of an instrument able to detect all the species simultaneously becomes necessary for traceability and authentication purposes. Approaches based on DNA barcoding represent an effective alternative to DNA fingerprinting methods in plant identification since they do not require the knowledge of the whole genome of an organism, being based on the exploitation of one or few genomic regions [11]. DNA barcoding shows two important advantages: the requirement to amplify a very short DNA region (a few hundred base pairs) and the widespread use of plastidial genome, which is more preserved during industrial processing [85]. Moreover, the availability of several plant DNA barcoding databases considerably simplifies species detection and identification $[103,119,121]$. Nevertheless, DNA barcoding presents some important limitations. First, only the species for which a reference is available can be identified; therefore, database incompleteness greatly affects the reliability of analysis [109]. Another important limit of DNA barcoding is that it can only be applied to identify monophyletic species, since polyphyletic and paraphyletic species do not display a clear barcode gap (i.e., a gap between frequency distributions between intra- and interspecific distances). The absence of a barcoding gap makes the definition of a threshold value to identify species impossible, generating either false negatives (species missed) or false positives (false species) [130]. This consideration makes evident the limitations of adopting a barcode-based strategy for cultivar distinction. Therefore, in some cases, a combined approach of molecular markers and DNA barcode would be the best strategy for an accurate and exhaustive authentication analysis [72,97]. 
Whole metagenome sequencing is the best strategy for authenticity, since it allows for the detection of additives, poisonous plants, allergens, and any other kind of adulterants fraudulently or accidentally added to a food-borne product. The main limitation of NGSbased methods in agri-food authentication is the obtainment of sufficiently high-quality DNA. This step is crucial to ensure that all DNA sequences present in a food-borne sample are properly identified [113]. A large number of DNA extraction protocols are now available for different kinds of foods including highly processed products (Table 3). These protocols take into account the specific features of a product implementing a series of steps aiming at the collection of a minimum amount of sufficient quality DNA on one hand, and the removal of inhibitors on the other. In some cases, the tuned protocol resulted in being highly effective in isolating DNA suitable for high throughput approaches [65,120]. Despite the great potential, the current use of NGS within the agri-food authentication and traceability sector is limited compared to the more established techniques. In the near future, the technological advances of NGS techniques, along with a cost reduction and more user-friendly options for analysis, will make these approaches increasingly widespread in food authenticity.

\section{Conclusions}

Agri-food traceability and authentication require reliable and accurate methods for the identification of plant species and varieties in a wide collection of fresh and processed food, without ambiguity. The possibility of being aware of the composition of a food has assumed increasing importance among consumers, thanks to the action of mass communication concerning the relevance "of knowing what one is eating". Among the different traceability techniques, molecular approaches are gaining increasing interest due to their significant advantages compared to the physico-chemical approaches.

There are many various molecular methods suitable for agri-food surveillance. Some of them such as the molecular marker-based approaches have been extensively experienced and used in the agri-food sector; several authors have described their main applications in detail. Here, we presented the advances of these approaches and their most recent employment in agri-food traceability and authentication. Moreover, we provided an extensive description of the most innovative approaches such as isothermal amplificationbased methods and DNA metabarcoding, which have only recently found application in agri-food surveillance. We highlighted their potential and prospects by showing the latest works on traceability and authentication based on the use of these methods. Finally, the description of the main advantages and limits of each molecular method will represent an effective prompt for anyone who wants to find the best method to authenticate or trace a specific agri-food.

The wide panel of molecular techniques to traceability and authentication in the agrifood sector constitutes a powerful tool to protect both producers and consumers, ensuring consumer freedom of choice and improving the transparency of food production systems, therefore allowing honest producers to adequately promote their food products.

Author Contributions: Conceptualization, V.F. and C.M.; Methodology, V.F., I.M., and M.M.M.; Data curation, V.F., M.A.S., and C.D.G.; Writing-original draft preparation, V.F.; Writing-review and editing, V.F., I.M., M.M.M., M.A.S., C.D.G., and C.M.; Supervision, C.M. All authors have read and agreed to the published version of the manuscript.

Funding: This research received no external funding. The APC was funded by MIUR-PON Ricerca e Innovazione 2014-2020 (project AIM1809249-attività 2, linea 1).

Conflicts of Interest: The authors declare no conflict of interest. 


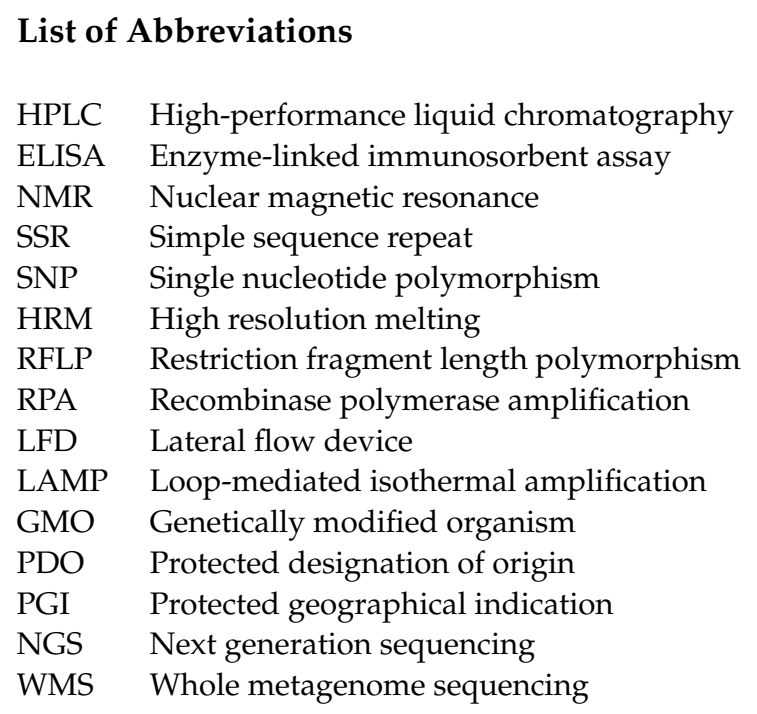

\section{References}

1. Aung, M.M.; Chang, Y.S. Traceability in a food supply chain: Safety and quality perspectives. Food Control 2014, 39, 172-184. [CrossRef]

2. Ballin, N.Z.; Laursen, K.H. To target or not to target? Definitions and nomenclature for targeted versus non-targeted analytical food authentication. Trends Food Sci. Technol. 2019, 86, 537-543. [CrossRef]

3. Maitiniyazi, S.; Canavari, M. Exploring Chinese consumers' attitudes toward traceable dairy products: A focus group study. J. Dairy Sci. 2020, 103, 11257-11267. [CrossRef] [PubMed]

4. $\quad$ Pelegrino, B.O.; Silva, R.; Guimarães, J.T.; Coutinho, N.F.; Pimentel, T.C.; Castro, B.G.; Freitas, M.Q.; Esmerino, E.A.; Sant'Ana, A.S.; Silva, M.C.; et al. Traceability: Perception and attitudes of artisanal cheese producers in Brazil. J. Dairy Sci. 2020, 103, 4874-4879. [CrossRef]

5. Danezis, G.P.; Tsagkaris, A.S.; Camin, F.; Brusic, V.; Georgiou, C.A. Food authentication: Techniques, trends \& emerging approaches. Trends Analyt. Chem. 2016, 85, 123-132.

6. Lo, Y.T.; Shaw, P.C. DNA-based techniques for authentication of processed food and food supplements. Food Chem. 2018, 240, 767-774. [CrossRef]

7. Galimberti, A.; Casiraghi, M.; Bruni, I.; Guzzetti, L.; Cortis, P.; Berterame, N.M.; Labra, M. From DNA barcoding to personalized nutrition: The evolution of food traceability. Curr. Opin. Food Sci. 2019, 28, 41-48. [CrossRef]

8. Regulation (EU) No 1151/2012 of the European Parliament and of the Council of 21 November 2012 on Quality Schemes for Agricultural Products and Foodstuffs. Available online: https: / / eur-lex.europa.eu (accessed on 9 July 2021).

9. Martins-Lopes, P.; Gomes, S.; Pereira, L.; Guedes-Pinto, H. Molecular markers for food traceability. Food Technol. Biotechnol. 2013, 51, 198-207.

10. Scarano, D.; Rao, R. DNA markers for food products authentication. Diversity 2014, 6, 579-596. [CrossRef]

11. Corrado, G. Advances in DNA typing in the agro-food supply chain. Trends Food Sci. Technol. 2016, 52, 80-89. [CrossRef]

12. Abbas, O.; Zadravec, M.; Baeten, V.; Mikuš, T.; Lešić, T.; Vulić, A.; Prpić, J.; Jemeršić, L.; Pleadin, J. Analytical methods used for the authentication of food of animal origin. Food Chem. 2018, 246, 6-17. [CrossRef] [PubMed]

13. Wadood, S.A.; Boli, G.; Xiaowen, Z.; Hussain, I.; Yimin, W. Recent development in the application of analytical techniques for the traceability and authenticity of food of plant origin. Microchem. J. 2020, 152, 104295. [CrossRef]

14. Lohumi, S.; Lee, S.; Lee, H.; Cho, B.K. A review of vibrational spectroscopic techniques for the detection of food authenticity and adulteration. Trends Food Sci. Technol. 2015, 46, 85-98. [CrossRef]

15. Castro-Puyana, M.; Herrero, M. Metabolomics approaches based on mass spectrometry for food safety, quality and traceability. Trends Analyt. Chem. 2013, 52, 74-87. [CrossRef]

16. Zhao, Y.; Zhang, B.; Chen, G.; Chen, A.; Yang, S.; Ye, Z. Recent developments in application of stable isotope analysis on agro-product authenticity and traceability. Food Chem. 2014, 145, 300-305. [CrossRef] [PubMed]

17. Dymerski, T. Two-dimensional gas chromatography coupled with mass spectrometry in food analysis. Crit. Rev. Anal. Chem. 2018, 48, 252-278. [CrossRef]

18. Esteki, M.; Shahsavari, Z.; Simal-Gandara, J. Food identification by high performance liquid chromatography fingerprinting and mathematical processing. Food Res. Int. 2019, 122, 303-317. [CrossRef]

19. Nolvachai, Y.; Kulsing, C.; Marriott, P.J. Multidimensional gas chromatography in food analysis. Trends Analyt. Chem. 2017, 96, 124-137. [CrossRef]

20. Medina, S.; Perestrelo, R.; Silva, P.; Pereira, J.A.M.; Câmara, J.S. Current trends and recent advances on food authenticity technologies and chemometric approaches. Trends Food Sci. Technol. 2019, 85, 163-176. [CrossRef] 
21. Wu, L.; Li, G.; Xu, X.; Zhu, L.; Huang, R.; Chen, X. Application of nano-ELISA in food analysis: Recent advances and challenges. Trends Analyt. Chem. 2019, 113, 140-156. [CrossRef]

22. Ahmad, M.H.; Sahar, A.; Hitzmann, B. Fluorescence spectroscopy for the monitoring of food processes. In Measurement, Modeling and Automation in Advanced Food Processing; Hitzmann, B., Ed.; Springer: New York, NY, USA, 2017; Volume 161, pp. $121-151$.

23. Esteki, M.; Shahsavari, Z.; Simal-Gandara, J. Use of spectroscopic methods in combination with linear discriminant analysis for authentication of food products. Food Control 2018, 91, 100-112. [CrossRef]

24. Xu, Y.; Zhong, P.; Jiang, A.; Shen, X.; Li, X.; Xu, Z.; Shen, Y.; Sun, Y.; Lei, H. Raman spectroscopy coupled with chemometrics for food authentication: A review. Trends Analyt. Chem. 2020, 131, 116017. [CrossRef]

25. Consonni, R.; Cagliani, L.R. The potentiality of NMR-based metabolomics in food science and food authentication assessment. Magn Reson Chem. 2019, 57, 558-578. [CrossRef]

26. Rubert, J.; Zachariasova, M.; Hajslova, J. Advances in high-resolution mass spectrometry based on metabolomics studies for food-A review. Food Addit. Contam. Part A 2015, 32, 1685-1708. [CrossRef]

27. Papapetros, S.; Louppis, A.; Kosma, I.; Kontakos, S.; Badeka, A.; Kontominas, M.G. Characterization and differentiation of botanical and geographical origin of selected popular sweet cherry cultivars grown in Greece. J. Food Compos. Anal. 2018, 72, 48-56. [CrossRef]

28. Watanabe, E.; Miyake, S. Direct determination of neonicotinoid insecticides in an analytically challenging crop such as Chinese chives using selective ELISAs. J. Environ. Sci. Health Part B 2018, 53, 707-712. [CrossRef] [PubMed]

29. Hongsibsong, S.; Prapamontol, T.; Xu, T.; Hammock, B.D.; Wang, H.; Chen, Z.J.; Xu, Z.L. Monitoring of the organophosphate pesticide chlorpyrifos in vegetable samples from local markets in Northern Thailand by developed immunoassay. Int. J. Environ. Res. Public Health 2020, 17, 4723. [CrossRef] [PubMed]

30. Tan, J.; Li, R.; Jiang, Z.T.; Tang, S.H.; Wang, Y.; Shi, M.; Xiao, Y.Q.; Jia, B.; Lu, T.X.; Wang, H. Synchronous front-face fluorescence spectroscopy for authentication of the adulteration of edible vegetable oil with refined used frying oil. Food Chem. 2017, 217, 274-280. [CrossRef] [PubMed]

31. Huo, Y.; Kamal, G.M.; Wang, J.; Liu, H.; Zhang, G.; Hu, Z.; Anwar, F.; Du, H. 1H-NMRbased metabolomics for discrimination of rice from different geographical origins of China. J. Cereal Sci. 2017, 76, 243-252. [CrossRef]

32. Longobardi, F.; Innamorato, V.; Di Gioia, A.; Ventrella, A.; Lippolis, V.; Logrieco, A.F.; Catucci, L.; Agostiano, A. Geographical origin discrimination of lentils (Lens culinaris Medik.) using 1H-NMR fingerprinting and multivariate statistical analyses. Food Chem. 2017, 237, 743-748. [CrossRef]

33. Salazar, M.O.; Pisano, P.L.; Gonzalez Sierra, M.; Furlan, R.L.E. NMR and multivariate data analysis to assess traceability of argentine citrus. Microchem. J. 2018, 141, 264-270. [CrossRef]

34. Drivelos, S.A.; Georgiou, C.A. Multi-element and multi-isotope-ratio analysis to determine the geographical origin of foods in the European Union. Trends Anal. Chem. 2012, 40, 38-51. [CrossRef]

35. Mahne Opatić, A.; Nečemer, M.; Lojen, S.; Masten, J.; Zlatić, E.; Šircelj, H.; Stopar, D.; Vidrih, R. Determination of geographical origin of commercial tomato through analysis of stable isotopes, elemental composition and chemical markers. Food Control 2018, 89, 133-141. [CrossRef]

36. Zambianchi, S.; Soffritti, G.; Stagnati, L.; Patrone, V.; Morelli, L.; Vercesi, A.; Busconi, M. Applicability of DNA traceability along the entire wine production chain in the real case of a large Italian cooperative winery. Food Control 2021, 124, 107929. [CrossRef]

37. Chedid, E.; Rizou, M.; Kalaitzis, P. Application of high resolution melting combined with DNA-based markers for quantitative analysis of olive oil authenticity and adulteration. Food Chemistry X 2020, 6, 100082. [CrossRef]

38. Gomes, S.; Breia, R.; Carvalho, T.; Carnide, V.; Martins-Lopes, P. Microsatellite high-resolution melting (SSR-HRM) to track olive genotypes: From field to olive oil. J. Food Sci. 2018, 83, 2415-2423. [CrossRef] [PubMed]

39. di Rienzo, V.; Fanelli, V.; Miazzi, M.M.; Savino, V.; Pasqualone, A.; Summo, C.; Giannini, P.; Sabetta, W.; Montemurro, C. A reliable analytical procedure to discover table grape DNA adulteration in industrial wines and musts. Acta Hortic. 2017, 1188, 365-370. [CrossRef]

40. Ben Ayed, R.; Rebai, A. Tunisian table olive oil traceability and quality using SNP genotyping and bioinformatics tools. BioMed Res. Int. 2019, 2019, 8291341. [CrossRef]

41. Piarulli, L.; Savoia, M.A.; Taranto, F.; D’Agostino, N.; Sardaro, R.; Girone, S.; Gadaleta, S.; Fucili, V.; De Giovanni, C.; Montemurro, C.; et al. A robust DNA isolation protocol from filtered commercial olive oil for PCR-based fingerprinting. Foods $2019,8,462$. [CrossRef]

42. Pereira, L.; Gomes, S.; Barrias, S.; Fernandes, J.R.; Martins-Lopes, P. Applying high-resolution melting (HRM) technology to olive oil and wine authenticity. Food Res. Int. 2018, 103, 170-181. [CrossRef]

43. Boccacci, P.; Chitarra, W.; Schneider, A.; Rolle, L.; Gambino, G. Single-nucleotide polymorphism (SNP) genotyping assays for the varietal authentication of 'Nebbiolo' musts and wines. Food Chem. 2020, 312, 126100. [CrossRef]

44. Barrias, S.; Fernandes, J.R.; Eiras-Dias, J.E.; Brazão, J.; Martins-Lopes, P. Label free DNA-based optical biosensor as a potential system for wine authenticity. Food Chem. 2019, 270, 299-304. [CrossRef]

45. Zhang, D.; Vega, F.E.; Infante, F.; Solano, W.; Johnson, E.S.; Meinhardt, L.W. Accurate differentiation of green beans of Arabica and Robusta coffee using nanofluidic array of Single Nucleotide Polymorphism (SNP) markers. J. AOAC Int. 2020, 103, 315-324. [CrossRef] 
46. Silletti, S.; Morello, L.; Gavazzi, F.; Gianì, S.; Braglia, L.; Breviario, D. Untargeted DNA-based methods for the authentication of wheat species and related cereals in food products. Food Chem. 2019, 271, 410-418. [CrossRef]

47. Morcia, C.; Bergami, R.; Scaramagli, S.; Ghizzoni, R.; Carnevali, P.; Terzi, V. A Chip Digital PCR assay for quantification of common wheat contamination in pasta production chain. Foods 2020, 9, 911. [CrossRef] [PubMed]

48. Dong, X.; Gao, D.; Dong, J.; Chen, W.; Li, Z.; Wang, J.; Liu, J. Mass ratio quantitative detection for kidney bean in lotus seed paste using duplex droplet digital PCR and chip digital PCR. Anal. Bioanal. Chem. 2020, 412, 1701-1707. [CrossRef] [PubMed]

49. Swetha, V.P.; Parvathy, V.A.; Sheeja, T.E.; Sasikumar, B. Authentication of Myristica fragrans Houtt. using DNA barcoding. Food Control 2017, 73, 1010-1015. [CrossRef]

50. Uncu, A.O. A trnH-psbA barcode genotyping assay for the detection of common apricot (Prunus armeniaca L.) adulteration in almond (Prunus dulcis Mill.). CyTA-J. Food 2020, 18, 187-194. [CrossRef]

51. Lagiotis, G.; Stavridou, E.; Bosmali, I.; Osathanunkul, M.; Haider, N.; Madesis, P. Detection and quantification of cashew in commercial tea products using High Resolution Melting (HRM) analysis. J. Food Sci. 2020, 85, 1629-1634. [CrossRef] [PubMed]

52. Ding, Y.; Jiang, G.; Huang, L.; Chen, C.; Sun, J.; Zhu, C. DNA barcoding coupled with high-resolution melting analysis for nut species and walnut milk beverage authentication. J. Sci. Food Agric. 2020, 100, 2372-2379. [CrossRef]

53. Bosmali, I.; Lagiotis, G.; Stavridou, E.; Haider, N.; Osathanunkul, M.; Pasentsis, K.; Madesis, P. Novel authentication approach for coffee beans and the brewed beverage using a nuclear-based species-specific marker coupled with high resolution melting analysis. LWT-Food Sci. Technol. 2021, 137, 110336. [CrossRef]

54. Valentini, P.; Galimberti, A.; Mezzasalma, V.; De Mattia, F.; Casiraghi, M.; Labra, M.; Pompa, P.P. DNA barcoding meets nanotechnology: Development of a universal colorimetric test for food authentication. Angew. Chem. Int. Ed. 2017, 56, 8094. [CrossRef] [PubMed]

55. Wu, Y.; Li, M.; Yang, Y.; Jiang, L.; Liu, M.; Wang, B.; Wang, Y. Authentication of small berry fruit in fruit products by DNA barcoding method. J. Food Sci. 2018, 83, 1494-1504. [CrossRef] [PubMed]

56. Zhao, M.; Wang, B.; Xiang, L.; Xiong, C.; Shi, Y.; Wu, L.; Meng, X.; Dong, G.; Xie, Y.; Sun, W. A novel onsite and visual molecular technique to authenticate saffron (Crocus sativus) and its adulterants based on recombinase polymerase amplification. Food Control 2019, 100, 117-121. [CrossRef]

57. Zhao, M.; Shi, Y.; Wu, L.; Guo, L.; Liu, W.; Xiong, C.; Yan, S.; Sun, W.; Chen, S. Rapid authentication of the precious herb saffron by loop-mediated isothermal amplification (LAMP) based on internal transcribed spacer 2 (ITS2) sequence. Sci. Rep. 2016, 6, 25370. [CrossRef]

58. Cibecchini, G.; Cecere, P.; Tumino, G.; Morcia, C.; Ghizzoni, R.; Carnevali, P.; Terzi, V.; Pompa, P.P. A fast, naked-eye assay for varietal traceability in the durum wheat production chain. Foods 2020, 9, 1691. [CrossRef] [PubMed]

59. Hu, Y.; Lu, X. Rapid pomegranate juice authentication using a simple sample-to-answer hybrid paper/polymer-based lab-on-achip device. ACS Sens. 2020, 5, 2168-2176. [CrossRef]

60. Lo, Y.T.; Shaw, P.C. Application of next-generation sequencing for the identification of herbal products. Biotechnol. Adv. 2019, 37, 107450. [CrossRef]

61. Raime, K.; Krjutškov, K.; Remm, M. Method for the identification of plant DNA in food using alignment-free analysis of sequencing reads: A case study on lupin. Front. Plant Sci. 2020, 11, 646. [CrossRef]

62. Lee, H.J.; Koo, H.J.; Lee, J.; Lee, S.C.; Lee, D.Y.; Giang, V.N.L.; Kim, M.; Shim, H.; Park, J.Y. Yoo, K.O.; et al. Authentication of Zanthoxylum species based on integrated analysis of complete chloroplast genome sequences and metabolite profiles. J. Agric. Food Chem. 2017, 65, 10350-10359. [CrossRef]

63. Kim, Y.; Shin, J.; Oh, D.R.; Kim, D.W.; Lee, H.S.; Choi, C. Complete chloroplast genome sequences of Vaccinium bracteatum Thunb., V. vitis-idaea L., and V. uliginosum L. (Ericaceae). Mitochondrial DNA B 2020, 5, 1843-1844. [CrossRef]

64. Khansaritoreh, E.; Salmaki, Y.; Ramezani, E.; Akbari Azirani, T.; Keller, A.; Neumann, K.; Alizadeh, K.; Zarre, S.; Beckh, G.; Behling, H. Employing DNA metabarcoding to determine the geographical origin of honey. Heliyon 2020, 6, e05596. [CrossRef] [PubMed]

65. Beltramo, C.; Cerutti, F.; Brusa, F.; Mogliotti, P.; Garrone, A.; Squadrone, S.; Acutis, P.L.; Peletto, S. Exploring the botanical composition of polyfloral and monofloral honeys through DNA metabarcoding. Food Control 2021, 128, 108175.

66. Powell, W.; Machray, G.C.; Provan, J. Polymorphism revealed by simple sequence repeats. Trends Plant Sci. 1996, 1, $215-222$. [CrossRef]

67. Stagnati, L.; Soffritti, G.; Martino, M.; Bortolini, C.; Lanubile, A.; Busconi, M.; Marocco, A. Cocoa beans and liquor fingerprinting: A real case involving SSR profiling of CCN51 and "Nacional" varieties. Food Control 2020, 118, 107392. [CrossRef]

68. Pinczinger, D.; von Reth, M.; Hanke, M.V.; Flachowsky, H. SSR fingerprinting of raspberry cultivars traded in Germany clearly showed that certainty about the genotype authenticity is a prerequisite for any horticultural experiment. Eur. J. Hortic. Sci. 2020, 85, 79-85. [CrossRef]

69. Sabetta, W.; Miazzi, M.M.; di Rienzo, V.; Fanelli, V.; Pasqualone, A.; Montemurro, C. Development and application of protocols to certify the authenticity and traceability of Apulian typical products in olive sector. Riv. Ital. Delle Sostanze Grasse 2017, 94, 37-43.

70. Verdone, M.; Rao, R.; Coppola, M.; Corrado, G. Identification of zucchini varieties in commercial food products by DNA typing. Food Control 2018, 84, 197-204. [CrossRef]

71. Ganopoulos, I.; Argiriou, A.; Tsaftaris, A. Microsatellite high resolution melting (SSR-HRM) analysis for authenticity testing of protected designation of origin (PDO) sweet cherry products. Food Control 2011, 22, 532-541. [CrossRef] 
72. Bosmali, I.; Ganopoulos, I.; Madesis, P.; Tsaftaris, A. Microsatellite and DNA-barcode regions typing combined with High Resolution Melting (HRM) analysis for food forensic uses: A case study on lentils (Lens culinaris). Food Res. Int. 2012, 46, 141-147. [CrossRef]

73. di Rienzo, V.; Miazzi, M.M.; Fanelli, V.; Savino, V.; Pollastro, S.; Colucci, F.; Miccolupo, A.; Blanco, A.; Pasqualone, A.; Montemurro, C. An enhanced analytical procedure to discover table grape DNA adulteration in industrial musts. Food Control 2016, 60, 124-130. [CrossRef]

74. Pasqualone, A.; Montemurro, C.; Grinn-Gofron, A.; Sonnante, G.; Blanco, A. Detection of soft wheat in semolina and durum wheat bread by analysis of DNA microsatellites. J. Agric. Food Chem. 2007, 55, 3312-3318. [CrossRef] [PubMed]

75. Zhao, J.; Li, A.; Jin, X.; Pan, L. Technologies in individual animal identification and meat products traceability. Biotechnol. Biotechnol. Equip. 2020, 34, 48-57. [CrossRef]

76. Marrano, A.; Birolo, G.; Prazzoli, M.L.; Lorenzi, S.; Valle, G.; Grando, M.S. SNP-discovery by RAD-sequencing in a germplasm collection of wild and cultivated grapevines (V. vinifera L.). PLoS ONE 2017, 12, e0170655. [CrossRef] [PubMed]

77. Taranto, F.; D’Agostino, N.; Pavan, S.; Fanelli, V.; di Rienzo, V.; Sabetta, W.; Miazzi, M.M.; Zelasco, S.; Perri, E.; Montemurro, C. Single nucleotide polymorphism (SNP) diversity in an olive germplasm collection. Acta Hortic. 2018, 1199, 27-32. [CrossRef]

78. Pavan, S.; Bardaro, N.; Fanelli, V.; Marcotrigiano, A.R.; Mangini, G.; Taranto, F.; Catalano, D.; Montemurro, C.; De Giovanni, C.; Lotti, C.; et al. Genotyping by Sequencing of cultivated lentil (Lens culinaris Medik.) highlights population structure in the Mediterranean gene pool associated with geographic patterns and phenotypic variables. Front. Genet. 2019, 10, 872. [CrossRef]

79. Singh, R.; Iquebal, M.A.; Mishra, C.N.; Jaiswal, S.; Kumar, D.; Raghav, N.; Paul, S.; Sheoran, S.; Sharma, P.; Gupta, A.; et al. Development of model web-server for crop variety identification using throughput SNP genotyping data. Sci. Rep. 2019, 9, 5122. [CrossRef]

80. Akpertey, A.; Padi, F.K.; Meinhardt, L.; Zhang, D. Effectiveness of Single Nucleotide Polymorphism markers in genotyping germplasm collections of Coffea canephora using KASP assay. Front. Plant Sci. 2021, 11, 612593. [CrossRef]

81. Spaniolas, S.; Bazakos, C.; Tucker, G.A.; Bennett, M.J. Comparison of SNP-based detection assays for food analysis: Coffee authentication. J. AOAC Int. 2014, 97, 4. [CrossRef]

82. Fang, W.; Meinhardt, L.W.; Mischke, S.; Bellato, C.M.; Motilal, L.; Zhang, D. Accurate determination of genetic identity for a single cacao bean, using molecular markers with a nanofluidic system, ensures cocoa authentication. J. Agric. Food Chem. 2014, 62, 481-487. [CrossRef]

83. Fang, W.P.; Meinhardt, L.W.; Tan, H.W.; Zhou, L.; Mischke, S.; Zhang, D. Varietal identification of tea (Camellia sinensis) using nanofluidic array of single nucleotide polymorphism (SNP) markers. Hortic. Res. 2014, 1, 14035. [CrossRef]

84. Nielsen, R.; Paul, J.S.; Albrechtsen, A.; Song, Y.S. Genotype and SNP calling from next-generation sequencing data. Nat. Rev. Genet. 2011, 12, 443-451. [CrossRef]

85. Galimberti, A.; De Mattia, F.; Losa, A.; Bruni, I.; Federici, S.; Casiraghi, M.; Martellos, S.; Labra, M. DNA barcoding as a new tool for food traceability. Food Res. Int. 2013, 50, 55-63. [CrossRef]

86. Sonnante, G.; Montemurro, C.; Morgese, A.; Sabetta, W.; Blanco, A.; Pasqualone, A. DNA microsatellite region for a reliable quantification of $\sim$ soft wheat adulteration in durum wheat-based foodstuffs by real-time PCR. J. Agric. Food Chem. 2009, 57, 10199-1020411. [CrossRef] [PubMed]

87. Matsuoka, Y.; Arami, S.; Sato, M.; Haraguchi, H.; Kurimoto, Y.; Imai, S.; Tanaka, K.; Mano, J.; Furui, S.; Kitta, K. Development of methods to distinguish between durum/common wheat and common wheat in blended flour using PCR. J. Food Hyg. Soc. Jpn. 2012, 53, 195-202. [CrossRef] [PubMed]

88. Voorhuijzen, M.M.; van Dijk, J.P.; Prins, T.W.; Van Hoef, A.M.A.; Seyfarth, R.; Kok, E.J. Development of a multiplex DNA-based traceability tool for crop plant materials. Anal. Bioanal. Chem. 2012, 402, 693-701. [CrossRef] [PubMed]

89. Morisset, D.; Stebih, D.; Milavec, M.; Gruden, K.; Zel, J. Quantitative analysis of food and feed samples with droplet digital PCR. PLoS ONE 2013, 8, e62583. [CrossRef]

90. Low, H.; Chan, S.J.; Soo, G.H.; Ling, B.; Tan, E.L. Clarity ${ }^{\mathrm{TM}}$ digital PCR system: A novel platform for absolute quantification of nucleic acids. Anal. Bioanal. Chem. 2017, 409, 1869-1875. [CrossRef] [PubMed]

91. Demeke, T.; Dobnik, D. Critical assessment of digital PCR for the detection and quantification of genetically modified organisms. Anal. Bioanal. Chem. 2018, 410, 4039-4050. [CrossRef]

92. He, L.; Simpson, D.J.; Gänzle, M.G. Detection of enterohaemorrhagic Escherichia coli in food by droplet digital PCR to detect simultaneous virulence factors in a single genome. Food Microbiol. 2020, 90, 103466. [CrossRef]

93. Pierboni, E.; Rondini, C.; Torricelli, M.; Ciccone, L.; Tovo, G.R.; Mercuri, M.L.; Altissimi, S.; Haouet, N. Digital PCR for analysis of peanut and soybean allergens in foods. Food Control 2018, 92, 128-136. [CrossRef]

94. Hebert, P.D.N.; Ratnasingham, S.; deWaard, J.R. Barcoding animal life: Cytochrome c oxidase subunit 1 divergences among closely related species. Proc. Royal Soc. B-Biol. Sci. 2003, 270, S96-S99. [CrossRef]

95. Liu, Y.; Wang, X.; Wang, L.; Chen, X.; Pang, X.; Han, J. A nucleotide signature for the identification of American ginseng and its products. Front. Plant Sci. 2016, 18, 319. [CrossRef] [PubMed]

96. Uncu, A.T.; Uncu, A.O. Plastid trnH-psbA intergenic spacer serves as a PCR-based marker to detect common grain adulterants of coffee (Coffea arabica L.). Food Control 2018, 91, 32-39. [CrossRef]

97. Bosmali, I.; Ordoudi, S.A.; Tsimidou, M.Z.; Madesis, P. Greek PDO saffron authentication studies using species specific molecular markers. Food Res. Int. 2017, 100, 899-907. [CrossRef] [PubMed] 
98. Liu, Y.; Xiang, L.; Zhang, Y.; Lai, X.; Xiong, C.; Li, J.; Su, Y.; Sun, W.; Chen, S. DNA barcoding based identification of Hippophae species and authentication of commercial products by high resolution melting analysis. Food Chem. 2018, 242, 62-67. [CrossRef] [PubMed]

99. Ballin, N.Z.; Onaindia, J.O.; Jawad, H.; Fernandez-Carazo, R.; Maquet, A. High-resolution melting of multiple barcode amplicons for plant species authentication. Food Control 2019, 105, 141-150. [CrossRef]

100. Gong, L.; Qiu, X.H.; Huang, J.; Xu, W.; Bai, J.Q.; Zhang, J.; Su, H.; Xu, C.M.; Huang, Z.H. Constructing a DNA barcode reference library for southern herbs in China: A resource for authentication of southern Chinese medicine. PLoS ONE 2018, 13, e0201240.

101. Kane, N.C.; Cronk, Q. Botany without borders, barcoding in focus. Mol. Ecol. 2008, 17, 5175-5176. [CrossRef]

102. Kane, N.; Sveinsson, S.; Dempewolf, H.; Yang, J.Y.; Zhang, D.; Engels, J.M.M.; Cronk, Q. Ultra-barcoding in cacao (Theobroma spp.; Malvaceae) using whole chloroplast genomes and nuclear ribosomal DNA. Am. J. Bot. 2012, 99, 320-329. [CrossRef] [PubMed]

103. Ratnasingham, S.; Hebert, P.D.N. BOLD: The Barcode of Life Data System (http://www.barcodinglife.org). Mol. Ecol. Notes 2007, 7, 355-364. [CrossRef]

104. Leonardo, S.; Toldrà, A.; Campàs, M. Biosensors based on isothermal DNA amplification for bacterial detection in food safety and environmental monitoring. Sensors 2021, 21, 602. [CrossRef]

105. Santiago-Felipe, S.; Tortajada-Genaro, L.A.; Puchades, R.; Maquieira, A. Recombinase polymerase and enzyme-linked immunosorbent assay as a DNA amplification-detection strategy for food analysis. Anal. Chim. Acta 2014, 811, 81-87. [CrossRef] [PubMed]

106. Zhang, X.; Lowe, S.B.; Gooding, J.J. Brief review of monitoring methods for loop-mediated isothermal amplification (LAMP). Biosens. Bioelectron. 2014, 61, 491-499. [CrossRef] [PubMed]

107. Wong, Y.P.; Othman, S.; Lau, Y.L.; Radu, S.; Chee, H.Y. Loop-mediated isothermal amplification (LAMP): A versatile technique for detection of micro-organisms. J. Appl. Microbiol. 2017, 124, 626-643. [CrossRef] [PubMed]

108. Li, R.; Wang, C.; Ji, L.; Zhao, X.X.; Liu, M.; Zhang, D.; Shi, J. Loop mediated isothermal amplification (LAMP) assay for GMO detection: Recent progresses and future perspectives. Open Access Libr. J. 2015, 2, e1264.

109. Wilkinson, M.J.; Szabo, C.; Ford, C.S.; Yarom, Y.; Croxford, A.E.; Camp, A.; Gooding, P. Replacing Sanger with Next Generation Sequencing to improve coverage and quality of reference DNA barcodes for plants. Sci. Rep. 2017, 7, 46040. [CrossRef]

110. Kumar, K.R.; Cowley, M.J.; Davis, R.L. Next-Generation Sequencing and emerging technologies. Semin. Thromb. Hemost. 2019, 45, 661-673. [CrossRef]

111. Ripp, F.; Krombholz, C.F.; Liu, Y.; Weber, M.; Schäfer, A.; Schmidt, B.; Köppel, R.; Hankeln, T. All-Food-Seq (AFS): A quantifiable screen for species in biological samples by deep DNA sequencing. BMC Genom. 2014, 15, 639. [CrossRef]

112. Beck, K.L.; Haiminen, N.; Chambliss, D.; Edlund, S.; Kunitomi, M.; Huang, B.C.; Kong, N.; Ganesan, B.; Baker, R.; Markwell, P.; et al. Monitoring the microbiome for food safety and quality using deep shotgun sequencing. NPJ Sci Food 2021, 5, 3. [CrossRef]

113. Haynes, E.; Jimenez, E.; Pardo, M.A.; Helyar, S.J. The future of NGS (Next Generation Sequencing) analysis in testing food authenticity. Food Control 2019, 101, 134-143. [CrossRef]

114. Haiminen, N.; Edlund, S.; Chambliss, D.; Kunitomi, M.; Weimer, B.C.; Ganesan, B.; Baker, R.; Markwell, P.; Davis, M.; Huang, C.; et al. Food authentication from shotgun sequencing reads with an application on high protein powders. NPJ Sci Food 2019, 3, 24. [CrossRef]

115. Zhang, N.; Ramachandran, P.; Wen, J.; Duke, J.A.; Metzman, H.; McLaughlin, W.; Ottesen, A.R.; Timme, R.E.; Handy, S.M. Development of a reference standard library of chloroplast genome sequences, GenomeTrakrCP. Planta Med. 2017, 83, 1420-1430. [CrossRef]

116. Bruno, A.; Sandionigi, A.; Agostinetto, G.; Bernabovi, L.; Frigerio, J.; Casiraghi, M.; Labra, M. Food tracking perspective: DNA metabarcoding to identify plant composition in complex and processed food products. Genes 2019, 10, 248. [CrossRef]

117. Speranskaya, A.S.; Khafizov, K.; Ayginin, A.A.; Krinitsina, A.A.; Omelchenko, D.O.; Nilova, M.V.; Severova, E.E.; Samokhina, E.N.; Shipulin, G.A.; Logacheva, M.D. Comparative analysis of Illumina and Ion Torrent high-throughput sequencing platforms for identification of plant components in herbal teas. Food Control 2018, 93, 315-324. [CrossRef]

118. Frigerio, J.; Gorini, T.; Galimberti, A.; Bruni, I.; Tommasi, N.; Mezzasalma, V.; Labra, M. DNA barcoding to trace Medicinal and Aromatic Plants from the field to the food supplement. J. Appl. Bot. Food Qual. 2019, 92, 33-38.

119. Banchi, E.; Ametrano, C.G.; Greco, S.; Stanković, D.; Muggia, L.; Pallavicini, A. PLANiTS: A curated sequence reference dataset for plant ITS DNA metabarcoding. Database 2020, 2020, baz155. [CrossRef] [PubMed]

120. Utzeri, V.J.; Ribani, A.; Schiavo, G.; Bertolini, F.; Bovo, S.; Fontanesi, L. Application of next generation semiconductor based sequencing to detect the botanical composition of monofloral, polyfloral and honeydew honey. Food Control 2018, 86, 342-349. [CrossRef]

121. Gostel, M.R.; Zúñiga, J.D.; Kress, W.J.; Funk, V.A.; Puente-Lelievre, C. Microfluidic Enrichment Barcoding (MEBarcoding): A new method for high throughput plant DNA barcoding. Sci. Rep. 2020, 10, 8701. [CrossRef] [PubMed]

122. Xia, Y.; Chen, F.; Jiang, L.; Li, S.; Zhang, J. Development of an efficient method to extract DNA from refined soybean oil. Food Anal. Methods 2021, 14, 196-207. [CrossRef]

123. Pereira, L.; Guedes-Pinto, H.; Martins-Lopes, P. An enhanced method for Vitis vinifera L. DNA extraction from wines. Am. J. Enol. Vitic. 2011, 62, 4. [CrossRef]

124. Bojang, K.P.; Kuna, A.; Pushpavalli, S.N.C.V.L.; Sarkar, S.; Sreedhar, M. Evaluation of DNA extraction methods for molecular traceability in cold pressed, solvent extracted and refined groundnut oils. J. Food Sci. Technol. 2021, 1-7. [CrossRef] 
125. Soares, S.; Amaral, J.S.; Oliveira, M.B.P.P.; Mafra, I. Improving DNA isolation from honey for the botanical origin identification. Food Control 2015, 48, 130-136. [CrossRef]

126. López-Calleja, I.M.; de la Cruz, S.; Martín, R.; González, I.; García, T. Duplex real-time PCR method for the detection of sesame (Sesamum indicum) and flaxseed (Linum usitatissimum) DNA in processed food products. Food Addit. Contam. Part A 2015, 32, 1772-1785. [CrossRef] [PubMed]

127. Kumar, P.; Gupta, V.; Misra, A.; Modi, D.; Pandey, B. Potential of molecular markers in plant biotechnology. Plant Omics 2009, 4, 141-162.

128. Jagadeesan, B.; Gerner-Smidt, P.; Allard, M.W.; Leuillet, S.; Winkler, A.; Xiao, Y.; Chaffron, S.; Van Der Vossen, J.; Tang, S.; Katase, M.; et al. The use of next generation sequencing for improving food safety: Translation into practice. Food Microbiol. 2019, 79, 96-115. [CrossRef]

129. Galimberti, A.; Bruno, A.; Mezzasalma, V.; De Mattia, F.; Bruni, I.; Labra, M. Emerging DNA-based technologies to characterize food ecosystems. Food Res. Int. 2015, 69, 424-433. [CrossRef]

130. Besse, P.; Da Silva, D.; Grisoni, M. Plant DNA barcoding principles and limits: A case study in the Genus Vanilla. In Molecular Plant Taxonomy; Besse, P., Ed.; Springer: New York, NY, USA, 2021; Volume 2222, pp. 131-148. 